Omawiana publikacja stanowi interesującą pozycję, poruszającą w sposób przystępny zagadnienia absorbujące współczesnego człowieka. Pozornym mankamentem omawianej książki może być jej popularyzatorski charakter, chociaż, jak się wydaje, nie dla każdego czytelnika. Książka mimo takiego jej charakteru odznacza się głęboką wiedzą psychologiczną. Jej wartość to wciąż niezmienny temat poszukiwań człowieka, jakim jest wolność i sens życia. Pozycja ta może stać się inspiracją dla osób pragnących zrozumieć samych siebie i na nowo odczytać pojęcie wolności w kontekście współczesnych wyzwań. Książkę polecam nie tylko studentom psychologii, którzy wczytując się w nią, mogą wyzwolić się ze schematów patrzenia na człowieka tylko przez różne koncepcje psychologiczne. Książka ta pozwoli zobaczyć, że człowiek jest tajemnica, nad którą pochylać się należy ze świadomością, że nie można jej niszczyć. Dotykając jej, psycholog musi ją szanować, rozumieć, wysłuchać i czasami milczeć. Może warto, by po tę pozycję sięgnęli również nauczyciele, borykający się z różnymi problemami młodego człowieka i rodzice chcący wychować swoje dziecko jak najlepiej. Bo zarówno nauczyciele, jak i rodzice znajdą w niej twarde argumenty za tym, że wolność to nie samowola wychowawcza, ale odpowiedzialność, wybór i zadanie każdego człowieka do całościowego rozwoju swojej osobowości.

Dariusz Buksik*

\title{
Shirley Trickett, Lęk i depresja. Jak radzić sobie z lękiem i depresją, Wy- dawnictwo Jedność, Kielce 2006, ss. 151.
}

Egzystencja współczesnego człowieka nacechowana jest ogromnym poczuciem lęku i depresji, które często trudno racjonalnie uzasadnić. Człowiek mimo wielu powodów do radości, chęci życia, nadziei, zadowolenia, takich jak dobra praca, kochająca rodzina i oddani przyjaciele, znajduje się w stanie lęku i depresji. W ten stan wprowadza się często sam, a czasami wpędzany jest w sposób mechaniczny przez sytuacje niezrozumiałe dla niego samego. Lęk czy też jakiś rodzaj depresji wywołany jest w nim przez te same czynniki, które go w jakimś momencie życia bardzo uszczęśliwiają, przynoszą mu pełne zadowolenie. Po jakimś czasie jednak zaczynają być odczytywane negatywnie. I tak, to co było radościa, przykładowo posiadanie rodziny, w sytuacji pojawienia się problemu w rodzinie, zaczyna łączyć się z lękiem przed utratą spokoju rodzinnego. Dobrze płatna praca zaczyna wiązać się z lękiem o jej utratę itp.

Sytuacje lękorodne i depresyjne nader często zdarzają się w dzisiejszym społeczeństwie, które charakteryzuje się walką jednostek o jak najwięcej dobra dla

* Ks. dr Dariusz Buksik SDB, adiunkt w Instytucie Psychologii Uniwersytetu Kardynała Stefana Wyszyńskiego w Warszawie. 
siebie. Wszelkie przeszkody na drodze do osiagnnięcia tego dobra - materialnego, duchowego, intelektualnego i każdego innego mogą tworzyć niepokojące stany w postaci lęku i depresji. Powstają też inne stany, takie jak ucieczka przed życiem, pustka egzystencjalna czy też nuda, prowadzące do uzależnień od różnych środków, niekoniecznie chemicznych.

Shirley Trickett swoją pozycją nie tylko wpisuje się w szeroką przestrzeń dyskusji naukowej na temat lęku i depresji, ale z niezwykłym wyczuciem prowadzi czytelnika po tajnikach tych trudnych problemów dotykających współczesnego człowieka. Jest to książka nie tyle sensu stricte naukowa, choć pokazana jest w niej przestań wiedzy naukowej, co dzięki językowi popularno-naukowemu wprowadza przeciętnego czytelnika $\mathrm{w}$ świat dla niego bardzo często niezrozumiały i zawiły. Jednocześnie przedstawiając ten trudny i bolesny świat, wskazuje drogi pomocy i wyjścia z kryzysów dla osób je przeżywających. Autorka książki, odwołując się do wieloletnich doświadczeń pracy z osobami dotkniętymi różnego rodzaju stanami lęku i depresji, czyni to z pewną lekkością, a zarazem wielkim znawstwem materii przedmiotu. Książka jest raczej poradnikiem niż rozprawą naukową. Wskazuje na to już sam podtytuł, w którym autorka stawia pytanie: Jak radzić sobie z lękiem i depresją? Książka Shirley Trickett poucza, w jaki sposób dotrzeć do pacjenta cierpiącego na stany lęku i depresji. Pokazuje, iż należy nad pacjentem zatrzymać się z większą uwagą i głębszym współodczuwaniem. Pacjent jest bowiem żywą istotą, to podmiot myślący, czujący, uciekający przed bólem, a nie tylko człowiek dotknięty jakimś rodzajem choroby, którą znanymi środkami farmaceutycznymi należy zwalczyć. Autorka była jedną z pierwszych osób wskazujących na fakt, że trankwilizatory są lekami nie tylko pomagającymi czy też działającymi kojąco na pacjenta $\mathrm{w}$ leczeniu psychoz lub nerwic, ale również uzależniają. Stała się tą osobą która pomagała wielu pacjentom, stosując inne metody leczenia niż podawanie środków farmakologicznych. W ten sposób również zwróciła uwagę środowiska medycznego na ten problem, którego efektem jest już dzisiaj przekonanie, iż trankwilizatory nie są zbyt skuteczne w zwalczaniu lęku.

Książka składa się z dwóch części. Pierwsza część zatytułowana jest Zrozumieć lęk $i$ depresję i zawiera trzynaście krótkich podrozdziałów, natomiast druga część to sześć równie krótkich podrozdziałów pokazujących rolę i możliwości samodzielnej terapii lęku i depresji. W niektórych punktach możemy znaleźć przypisy, w których autorka wyjaśnia zawiłe terminy medyczne. Książka nie posiada bogatej literatury naukowej, która w warunkach naukowości wskazuje na merytoryczność i wagę danej pozycji. Można z całą pewnością wnosić jednak, że widza zawarta w tej książce nie jest tylko oparta na ogromnym doświadczeniu autorki w podejściu do pacjenta, co w moim przekonaniu jest właśnie atutem tej pozycji, ale również na konkretnej wiedzy, z którą autorka styka się na co dzień. Wiedza ta oparta jest na gruntownym wykształceniu oraz, jak możemy się dowiedzieć z wprowadzenia do książki, wynika z licznych naukowych dyskusji prowadzonych ze środowiskiem lekarskim, by przekonać je do swojej wizji pracy z pacjentem. 
W pierwszej części książki autorka wyjaśnia, iż istnieje ścisły związek pomiędzy psychiką a ciałem. Trzeba wciąż na nowo sobie uświadamiać, że jeśli ciało, umysł i duch nie są odpowiednio przygotowane, to nie dojdzie do pełnego powrotu do zdrowia. Leczenie należy stosować nie do jednej części ciała czy osobowości, ale do całej jej struktury. Czyli należy mieć świadomość, że system nerwowy związany jest z resztą ciała. Tak więc autorka wyjaśnia najpierw, czym jest zdrowie, by następnie ukazać, czym jest lęk i depresja. Aby przedstawić, dlaczego człowiek staje się lękliwy i depresyjny, autorka wyjaśnia działanie systemu nerwowego. Czyni to w sposób przejrzysty i zrozumiały dla każdego czytelnika. Uświadomienie sobie stanów, w których podrażniony jest układ nerwowy, pozwala zobaczyć, że w wielu sytuacjach stresowych czy też lękowych należy zwolnić rytm życia. Zwolnienie może uchronić przed wyczerpaniem nerwowym, prowadzącym do stanów lęku. W dalszej części książki autorka podaje konkretne objawy zaburzeń lękowych oraz odpowiada na pytanie, dlaczego u człowieka pojawia się nadmierna lękliwość, myśli samobójcze, stany paniki, obsesje, fobie czy kompulsje. Podaje też powody nadaktywności i bezsenności. Najciekawsze jest jednak to, iż ukazuje proste sposoby na to, co zrobić, gdy pojawią się takie stany w człowieku. Te proste sposoby pracy nad sobą mogą pomóc w samodzielnym radzeniu sobie ze stanami lęku i depresji. Inaczej mówiąc, mogą pomóc, by do takich stanów w ogóle nie doszło. Wydaje się, że dla czytelnika uważnie czytającego tę książkę pomocne mogą być rozdziały ukazujące powody wyczerpania nerwowego, zrozumienie stanu lęku i depresji, które są czymś odmiennym niż nieszczęście oraz zrozumienie, czym jest załamanie nerwowe. Dostosowanie się do prostych wskazówek autorki pozwoli czytelnikowi uniknąć takich stanów i cieszyć się normalnością życia. Interesujące są wskazania autorki dotyczące stosowania leków na stany lęku i depresji. Leki te mają być tak przyjmowane, aby nie uzależniły pacjenta od nich samych. Istotne są również wskazania na temat zastosowania innych, alternatywnych metod pomagających w leczeniu lęku i depresji. Ciekawy jest też rozdział, w którym autorka sugeruje fizyczne powody lęku i depresji.

Druga część książki jest przydatna w samodzielnej terapii lęku i depresji. Oczywiście samodzielna terapia może być tylko etapem wspomagającym w leczeniu konkretnego stanu lęku czy depresji. Wskazania opracowane i stosowane przez autorkę w swojej pracy z pacjentem pozwalają czytelnikowi uświadomić sobie, że wykorzystując rady Shirley Trickett sam może pomóc sobie w tym, aby nie doszło do stanu lęku i depresji. By uniknąć stanów depresji, wystarczy podejmować codziennie ruch na świeżym powietrzu, pracować - nawet w najmniejszej ilości, odpowiednio odżywiać się i prowadzić regularny tryb życia. Natomiast, aby bronić się przed lękiem, należy między innymi zwolnić tempo życia, starać się odpocząć w ciagu dnia czy też regularnie ćwiczyć ciało. Czytelnik znajdzie konkretne wskazówki, co należy uczynić, by w dzisiejszym zabieganym świecie nie zapędzać siebie w spiralę leku i depresji. W ostatnim rozdziale autorka odnosi się do relacji, jaką człowiek ma do Boga. Z pewną niepewnością pisze 
ten rozdział odnosząc go do osób, które wierzą, i prosząc jednocześnie, by osoby niewierzące nie czuły się urażone. Wskazuje w nim, że człowiek przepełniony lękiem, depresją jest zamknięty na rozwój duchowy, a co za tym idzie na rozwój całej swojej osobowości.

Książka Shirley Trickett jest cennym źródłem wiedzy dla osób, które zajmują się na co dzień pomocą człowiekowi. Nie chodzi tutaj tylko o psychoterapeutów zajmujących się profesjonalnie pomocą drugiemu człowiekowi, ale o szereg grup osób pracujących dzisiaj w szpitalach, ochronkach, domach starców, domach samotnej matki czy instytucjach państwowych wspomagających ludzi zagubionych. Książka warta jest polecenia studentom psychologii, pedagogiki, pracy socjalnej, nauczycielom, jak również duszpasterzom, którzy na co dzień spotykają się z osobami, które przeżywają stany lęku i depresji. Wiedza zawarta w tej książce może pomóc w lepszym rozwiązaniu wielu problemów tych ludzi. Również osoby pracujące na co dzień z osobami chorymi lepiej zrozumieją ich potrzeby i oczekiwania wobec opieki z ich strony, która może stać się pełniejsza, radośniejsza i trwalsza. Niewątpliwie walorem tej publikacji jest przejrzystość, łatwość czytania oraz praktyczne wskazania, które mogą być natychmiast wykorzystane w pracy z pacjentem.

Dariusz Buksik

\begin{abstract}
Malgorzata Slowik, Społeczno-pedagogiczne uwarunkowania kryzysów religijnych wspótczesnej mlodzieży polskiej, Wydawnictwo Naukowe Akademii Pomorskiej w Słupsku, Słupsk 2008, ss. 204.
\end{abstract}

Religijność jest jednym z najistotniejszych wymiarów, w jakich dokonuje się rozwój człowieka, ponieważ stara się on, jako istota rozumna, odnaleźć ostateczny sens świata oraz własnego w nim istnienia. Rozwój religijności nie przebiega płynnie. Towarzyszą mu liczne kryzysy, które wynikają z uwarunkowań wewnętrznych, psychicznych i duchowych, lub zewnętrznych - społecznych. Małgorzata Słowik postanowiła przyjrzeć się w swych poszukiwaniach z zakresu pedagogiki religii potencjalnym zewnętrznym źródłom kryzysów religijnych. Uznała, że są to uwarunkowania społeczno-pedagogiczne, choć we wprowadzeniu do książki wyjaśnia, jakie trudności związane są z tym sformułowaniem. Jest świadoma, że tylko niektóre $\mathrm{z}$ omawianych w pracy środowisk, w których żyje i rozwija się człowiek, podejmują świadome zabiegi, mające na celu kształtowanie jego religijności. Są to przede wszystkim rodzina i Kościół. W pozostałych środowiskach można jednak również odnaleźć takie działania, które mają charakter celowy, a oddziaływania wszystkich środowisk - świadome i nieświadome - łączy fakt, że wywołują względnie trwałe zmiany w osobowości. Badania prowadzone były metodą hermeneutyczną, źródłem dla nich była literatura 